\title{
People are obsessed with religion: The definitional dissonance of evangelical encounters in Myanmar
}

\author{
Michael Edwards
}

This article responds to recent calls to consider how religion is defined and deployed in and about Myanmar. Discussing local Pentecostal efforts to evangelise to Buddhists in contemporary Yangon, it presents the encounter with the religious other as one ground from which definitions of religion might emerge. I show that, by taking up new opportunities to share the gospel, believers enter into a long conversation between Christianity and Buddhism dating back to the colonial period. Tracing the different definitions of religion that this conversation generates, and attuning to the dissonances between them, might offer alternate ways for approaching what gets termed the religious and the secular in the study of Myanmar.

\section{Introduction}

To observe Myanmar's recent history is to be reminded that definitions are far from neutral. Who gets to define a concept is a question frequently caught up with workings of power unfolding across domains of law, politics, and religion. Indeed, the extent to which the meanings of those very categories in Myanmar have been and are subject to contestation - alongside democracy, citizenship, and indigeneity - speaks to the force of definitions to afford certain possibilities and foreclose others. There are clues to this force in the etymology of 'definition' itself, in the bounding and limiting actions implied by the Latin 'finire'. For its part, the Burmese word for definition $(a$ dei-pe) has in its Pali root the sense not just of 'sense', but also of 'purpose': a reminder, perhaps, of the intentions and tensions at play in processes and practices of definition.

One person unlikely to need such a reminder was the senior pastor at Hope, an independent Pentecostal church in downtown Yangon. ${ }^{1}$ Founded in the 1980s, Hope was recognised in Pentecostal circles for its commitment to evangelism, its dedication to sharing the gospel with non-believers. Roughly two thirds of its staff were employed as evangelists. This meant regular excursions to neighbourhoods on Yangon's peri-urban fringe to speak about Jesus to Buddhist households. I was discussing this work with the pastor one afternoon in early 2016 when there was a

Michael Edwards is a Smuts Research Fellow at the Centre of South Asian Studies, University of Cambridge. Correspondence in connection with this article may be addressed to: me467@cam.ac.uk.

Thanks to the members of the Yangon churches who made this fieldwork possible. Thanks also to Bénédicte Brac de la Perrière, Penny Edwards, Matthew Engelke, Deborah James, Ruth Streicher, Alicia Turner, Wai Phyo Maung, and the three anonymous reviewers for comments. Research was supported by the London School of Economics and the Royal Anthropological Institute.

${ }^{1}$ The names of churches and people have been changed, with the exception of wellknown individuals. 
knock on his glass office door. One of the church ministers entered and handed him a small pink post-it note with a number written on it: the latest figure for total members of his church. The pastor had been explaining how, thirty years earlier, God had given him a vision to travel from Chin State, in the west of the country, to Yangon to found a church that would 'shake Myanmar for Christ'. The post-it note spoke to the realisation of that vision, evincing how baptisms the previous weekend of a batch of 'new believers' (youn chi thu athiq) had increased church membership by about a dozen.

What impact, I asked, did the new conversion law have on this work? Introduced about six months earlier as part of a package of four 'Protection of Race and Religion Laws', this was to establish 'Religious Conversion Scrutinising and Registration Boards' at the local township level to which any person wanting to change their religion would need to present. The pastor claimed to be unfazed. Christians continued to face persecution, he said, notwithstanding the reforms that since around 2011 had allowed them to evangelise more publically. But they would continue irrespective of the law. For one thing, it was not really about them; passed at the behest of Buddhist nationalist groups, its real target was Myanmar's Muslims. It was also not yet clear, as is frequently the case in the country, how the law would be implemented. That really came down to local township officers. Most importantly though, it was a lot like the system of national ID cards: whether a person had 'Buddhist' or 'Christian' or 'Muslim' listed on the card as their religion was beside the point. What mattered was what they 'believed' (youn deh) in their 'heart' (seik hna'loun). After all, the pastor said, his church was not doing 'religion' (batha).

We might dismiss this as the performance of a familiar evangelical trope: the assertion that Christianity offers something radically different from mere 'religion'. This was certainly a constant refrain in Yangon churches during the fieldwork on which this paper is based, conducted over 18 months between 2014 and 2016. We might also read in the pastor's remark the familiar Protestant emphasis on interiority and the sincerity of personal conviction. ${ }^{3}$ In this paper, however, I situate the pastor's claim - his insistence that his church is not doing 'religion' - in relation to the work the concept performs in Myanmar. In doing so, I respond to recent calls to attend to how certain key categories - such as religion and politics - are used in discourse both in and about the country, especially in the growing body of analysis seeking to understand certain trends and events - rising nationalism, outbreaks of communal violence, episodes of ethnic cleansing - that have accompanied the country's apparent transition. ${ }^{4}$ Much of this analysis, in an echo of debates surrounding the Arab Spring, ${ }^{5}$

\footnotetext{
${ }^{2}$ Gil Anidjar, 'Secularism', Critical Inquiry, 31, 1 (2006): 52-77.

${ }^{3}$ Webb Keane Christian moderns: Freedom and fetish in the mission encounter (Berkeley: University of California Press, 2006).

${ }^{4}$ Alicia Turner, 'Myanmar: Contesting conceptual landscapes in the politics of Buddhism', Kyoto Review of Southeast Asia, 16 (2016), https://kyotoreview.org/issue19/myanmar-buddhism-conceptual-landscapes/. Accessed: 27 May 2018; Nick Cheesman, 'Introduction: Interpreting communal violence in Myanmar', Journal of Contemporary Asia, 47, 3 (2017): 335-352; Iselin Frydenlund, 'Protecting the sasana through law: Radical Buddhism and religious freedom in transitional Myanmar", in Religion, secularism and democracy in Southeast Asia, ed. Vidhu Verma
} (Delhi: Oxford University Press, 2019), pp. 194-212 
revolves around the issue of religion and its relationship to what is often glossed as the secular. The risk, however, as Alicia Turner reminds us, is that such terms come to be treated as fixed and neutral categories, thereby eliding Burmese moves 'to redefine or reshape the conceptual landscape in the local context ${ }^{6} .{ }^{6}$ Unpacking the pastor's claim that his church is not doing religion offers a possible window onto how some of this definitional labour is performed.

The concern with where to draw the line between religion and the secular - or between religion and politics, or religion and the state - is not new to studies of Myanmar. An earlier generation of scholars working after independence were also concerned with how these categories were demarcated, and what apparent slippages between them meant for the country's postcolonial future. ${ }^{7}$ The focus, in other words, is on the relationship between categories, ignoring 'the processes and practices by which the essences of the secular and the religious are continually defined and redefined. ${ }^{8}$ Turner's suggestion to attend to how ordinary Buddhists engage in the ongoing 'definition and redefinition of constitutive categories in Burmese life' is thus both urgent and long overdue. ${ }^{9}$ Hayward and Frydenlund's make a similar call to consider the 'Burmese Buddhist point of view' in understanding the place of the secular in Myanmar's legal arrangements. ${ }^{10}$ Also needed, however, is a recognition that the field of definitional labour is not an exclusively Buddhist space. It is one where religious others are active participants in its politics, not just mere objects of it. This article is therefore a response to provocations such as Turner's, but from an oblique angle, focusing not on Buddhists, but on local Pentecostals whose evangelism draws them onto this terrain. To take this approach is to recognise that defining religion 'is not merely an abstract intellectual exercise', but rather one that compels us to ask 'questions about where, by whom, and in what manner - i.e. in what social context and in what spirit - the definitions are produced and put into circulation., 11

Evangelists in Myanmar encounter definitions of religion already in circulation, even as they try to mobilise their own. Noteworthy is that these definitions are inflected with histories of past Christian-Buddhist encounter, inflections that have an ambiguous bearing on contemporary exchanges. For if the category of religion emerged in Burma, at least in part, in the course of the colonial encounter, and if this encounter, largely through the work of foreign missionaries, entwined religion with

\footnotetext{
${ }^{5}$ Hussein Ali Agrama, 'Reflections on secularism, democracy, and politics in Egypt', American Ethnologist, 39, 1 (2012): 26-31.

${ }^{6}$ Turner, 'Contesting conceptual landscapes'.

${ }^{7}$ See, for example, Donald Eugene Smith, Religion and politics in Burma (Princeton:

Princeton University Press, 1965); Fred R Von Der Mehden, 'The changing pattern of religion and politics in Burma', Studies on Asia 2 (1961): 63-73.

${ }^{8}$ Hussein Ali Agrama, Questioning secularism: Islam, sovereignty, and the rule of law in modern Egypt (Chicago: University of Chicago Press, 2012), p. 29.

${ }^{9}$ Turner, 'Contesting conceptual landscapes'.

${ }^{10}$ Susan Hayward and Iselin Frydenlund, 'Religion, secularism, and the pursuit of peace in Myanmar', The Review of Faith and International Affairs, 17, 4 (2019): 4.

${ }^{11}$ Talal Asad, 'Response to Gil Anidjar', Interventions: International Journal of

Postcolonial Studies, 11, 3 (2009): 398.
} 
belief, ${ }^{12}$ today's evangelists work to disentangle the two. Their message is often that 'religion' (batha) and 'belief' (youn chi chin) are not at all the same. If religion/politics is the binary on which much analysis of Myanmar pivots, religion/belief is the opposition that principally concerned evangelists at Hope and similar churches. It is with the apparent goal of rendering the latter distinction legible to Buddhist audiences that much energy is spent. The role of Protestant missionaries in the production of a category of religion grounded in belief is a familiar story across histories of colonialism. It is now axiomatic not just that the secular and religious are mutually constitutive categories, but that we can trace Christian geneaologies in definitions of religion - and attendant formations of the secular - across postcolonial settings. ${ }^{13}$ This axiom is borne out in Myanmar too, as we will see in what follows. But we will also see how today's evangelists work at cross-purposes with these legacies, evading the categories they have generated and loosening some of their hold.

In approaching these moves, it might be helpful to think about contemporary evangelism as the latest exchange in a 'long conversation' between Buddhism and Christianity in Myanmar - similar to what the Comaroffs observe in their study of the encounter between the Tswana and British missionaries in southern Africa. ${ }^{14}$ Doing so reveals how two centuries of Christian-Buddhist encounter have helped to shape how religion is lived and understood in Myanmar. But what it also shows is the extent to which this conversation has and continues to be shot through with definitional dissonances: slippages in the meanings of its key terms in their passage between different groups, and also between past and present. I suggest that these dissonances might be productive, though not necesarrily in aiding evangelism; the gospel has long received a mostly indifferent reaction from Buddhist audiences in Myanmar, and, the pink post-it note notwithstanding, there is no overwhelming evidence to suggest this has changed of late.

Rather, dissonances might be productive in two other ways. First, they afford space through which efforts to preach the gospel can exist at cross-purposes with state efforts to regulate religious difference. They are what allow Hope's senior pastor, for example, to pay attention to the post-it note while dismissing the conversion law assenting to belief's registration in one mode but not the other. Second, they provide a conceptual armature through which the karmic logic of Buddhism comes to stand as a

${ }^{12}$ Erik Braun, The birth of insight: Meditation, modern Buddhism, and the Burmese monk Ledi Sayadaw. (Chicago: Chicago University Press, 2013); Gustaaf Houtman, 'How a foreigner invented 'Buddhendom' in Burmese: From tha-tha-na to bok-da' ba-tha', Journal of the Anthropological Society of Oxford, 21, 2 (1990): 113-128; Alexey Kirichenko, 'From Thathanadaw to Theravâda Buddhism: Constructions of religion and religious identity in nineteenth- and early twentieth-century Myanmar', in Casting faiths: Imperialism and the transformation of religion in East and Southeast Asia, ed. Thomas David DuBois (New York: Palgrave Macmillan, 2009).

${ }^{13}$ Talal Asad, Genealogies of religion: Discipline and reasons of power in Christianity and Islam (Baltimore: Johns Hopkins Press, 1993); Talal Asad, Formations of the secular: Christianity, Islam, modernity (Stanford: Stanford University Press).

${ }^{14}$ Jean Comaroff and John L. Comaroff, Of revelation and revolution: Christianity, colonialism, and consciousness in South Africa, Vol. 1 (Chicago: University of Chicago Press, 1991). 
quintessential 'religion' when contrasted with the gospel that claims to transcend it. The first might involve a rejection of certain constituent elements of secularism, insofar as its modes of governance entail not just the privatisation of faith, but also the state's production and management of religious difference. ${ }^{15}$ The second might entail the rejection of secularity in the form of karma perceived as a disenchanted law of causality. Both suggest that attuning to definitional dissonances might point to alternate conceptual frames in use. Such dissonances were amplified amidst the country's fraught transition - a moment in which, for Christians at churches like Hope, God was finally 'saving' Myanmar. It is to this moment that we now turn.

\section{Saving Myanmar}

For the Pentecostal believers with whom I did fieldwork, the transition offered opportunities and challenges. The effects of recent political and economic changes were keenly felt, even if attitudes towards them remained ambivalent: new shopping malls springing up; the surge in smartphone use; the easing of censorship; the liberalisation of party politics leading to the NLD's electoral victory. These were the signs that 'God is moving in Myanmar'. But they were accompanied by rising costs of living, ongoing efforts to silence certain forms of dissent, and a growing scepticism about the NLD's ability to deliver the 'real change' it had promised its diverse constituents - especially, but not only, given constitutional constraints that continued to enshrine the military's role in civilian government. Like their Buddhist compatriots, Pentecostals wrestled with these contradictions. They too greeted the NLD's victory with enthusiasm, even as they were circumspect about whether it would have any substantive impact on their lives. In conversations in churches about the transition, an increasing degree of cynicism - a feeling that nothing was changing - was tempered by the acknowledgement that some things were in fact different. If the former was down to the recalcitrance of generals and their cronies, the latter was largely attributed to God.

One change these Christians pointed to was a greater freedom to organise large public gatherings. In the past, I was told, requests to hold such events were frequently denied, part of a program of persecution that also included the random closure of churches. Even the biggest cynics were willing to admit that, on this front at least, things had improved. Recent years had seen a burgeoning of public concerts and conferences held on a scale and with a frequency previously unimaginable. The English names of many - 'Awakening', 'History Maker', 'True Transformation' seemed not only to speak to the familiar evangelical emphasis on rupture, but also to index the reforms that had only recently made their organisation possible. Such linguistic moves rendered democratisation in the language of conversion, intertwined personal and political salvation, and implied that the country itself was, perhaps, on the precipice of being 'born again'.

This is not to say that local Christians were not pursuing evangelism prior to the start of the transition around 2011. Friends often reminded me of heroic steps taken even in

\footnotetext{
${ }^{15}$ On the entanglement of these two processes in formation of secularism, see Saba Mahmood, Religious difference in a secular age: A minority report (Princeton: Princeton University Press).
} 
the face of government persecution. According to some, the persecution in fact helped spark a 'revival' amongst local Christians who carried the burden of sharing the gospel with their Buddhist compatriots - especially after foreign missionaries were expelled in 1966, four years after Ne Win's coup. This weight was borne largely by members of those ethnic minorities most receptive to Christianity in the decades and centuries following the arrival in Rangoon of Adoniram Judson, the famous American Baptist missionary, in 1813. ${ }^{16}$ Today, many Pentecostal churches in Yangon trace roots back to a Pentecostal revival that swept through the northern part of Chin State, especially around the town of Tedim, in the early 1970s. ${ }^{17}$

American Baptist missionaries had worked successfully in the Chin Hills, a mountainous region where the Buddhism of lowland states had made few inroads, since the turn of the twentieth century. But the revival - replete with reports of healings, prophecies, and other miracles - prompted an exodus of believers from mainline to charismatic churches. As large numbers of people from this region migrated down to Yangon over subsequent decades, they brought this new faith, with its emphasis on the experience of the Holy Spirit and its commitment to evangelism, to Myanmar's largest city. Churches such as Hope emerge largely out of this history, meaning that contemporary evangelism in Yangon is not only an exchange in a extended dialogue between Christianity and Buddhism; it can also be situated in terms of a long series of different kinds of interactions between people from Myanmar's geographic and cultural periphery and those from its centre. ${ }^{18}$

My friend Sangpi's story was fairly representative in this respect. He was 28 years old, and had been born in Tedim and raised in Kalaymyo, a city in Sagaing Division and the foot of the Chin Hills. After studying at a bible college in Singapore, he had returned to Myanmar and now lived in Yangon, where he was an active participant in Christian events. One of these that I attended was in April 2016, when two of Myanmar's most prominent preachers, David Lah and San Toe, were given permission to hold an outdoor revival meeting at People's Park, in the shadow of the Shwedagon Pagoda (Figure 1). For Christians still sceptical about whether the transition had led to any concrete change, this event would have left them in little doubt. The previous October, the NLD's request to hold a campaign rally at the location had been denied; now, just seven months later, believers could meet there in large numbers to worship Jesus. That they could so in such close vicinity to the pagoda - a site whose potency in Burmese Buddhism is matched only by its central role in the country's colonial and postcolonial history ${ }^{19}$ - was not lost on attendees,

\footnotetext{
${ }^{16}$ On what Yoko Hayami calls a 'culture of evangelism' emerging amongst the Karen as early as the nineteenth century, see her article 'Karen culture of evangelism and early Baptist mission in nineteenth century Burma', Social Sciences and Missions, 31, 3-4 (2018): 251-283.

${ }^{17}$ On this revival, see Chin Khua Khai, 'Pentecostalism in Myanmar: An overview', Asian Journal of Pentecostal Studies, 51, 5 (2002): 58-63.

${ }^{18}$ F.K. Lehman, The structure of Chin society: A tribal people of Burma, adapted to a non-Western civilization (Urbana: University of Illinois Press, 1963); also cite Charney 2011

${ }^{19}$ Penny Edwards 'Grounds for protest: Placing Shwedagon pagoda in colonial and postcolonial history', Postcolonial Studies, 9, 2 (2006): 197-211.
} 
about three thousand of whom turned out over three nights during the first heavy rains of the wet season.

Packed under an enormous tent, they listened to sermons by the preachers, and sang along to rousing worship songs with Christian rock stars and rappers like Myo Gyi and J-Me. Sangpi was there to volunteer as the head usher. He told me, in a rare moment when not dashing around in the rain to organise overflow seating, that the event was only possible because Myanmar was now 'open' after decades of being 'closed'. The majority of the audience were Christian, he said, but the preaching and music would also touch the hearts of non-believers. He gestured to the small crowd of curious families and teenagers milling about the entrance on their way to the Happy Zone amusement park next door. It was a sentiment shared by David Lah when I interviewed two months later. 'As you saw in People's Park, it's possible!' he said. 'When God opens the door, nobody can close it.'

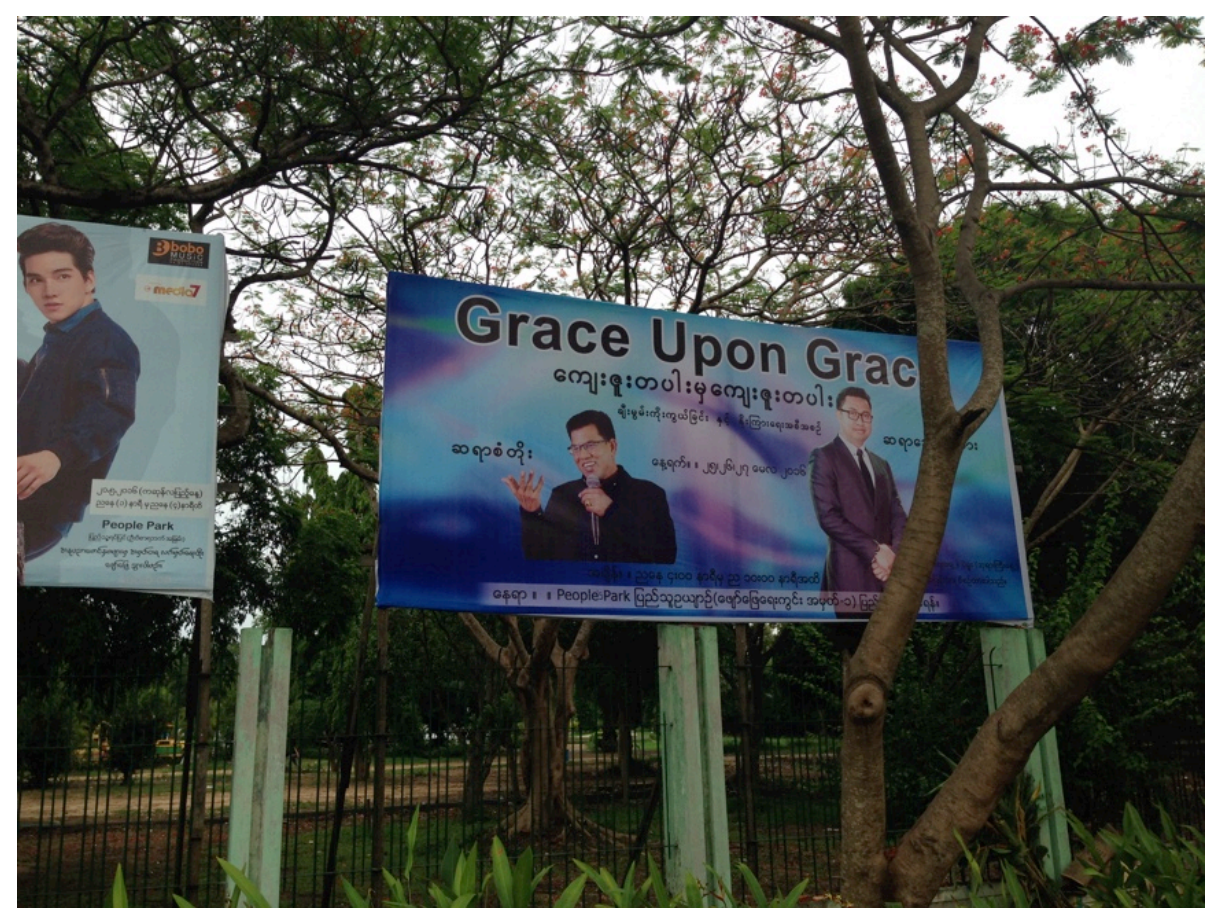

Figure 1: Signboard advertising event with preachers David Lah and San Toe at People's Park, Yangon, 2016. Photo by author.

How far, exactly, had God opened the door? Events like this gave some Christians the confidence to evangelise in ways more visible and audible than they had previously dared. Doing so entailed entering into a tentatively more open public sphere. But it was one over which the legacies of censorship and surveillance continued to loom large, and in which the voices of Buddhist nationalists were amplified amidst political and economic change, even as they also articulated longer standing currents. ${ }^{20}$ While

\footnotetext{
${ }^{20}$ Nyi Nyi Kyaw, 'Islamophobia in Buddhist Myanmar: The 969 movement and antiMuslim violence' in Islam and the state in Myanmar: Muslim-Buddhist relations and the politics of belonging, ed. Melissa Crouch (Oxford: Oxford University Press, 2016); Tharaphi Than, 'Nationalism, religion, and violence: Old and
} 
Muslims had been the primary focus 969 , MaBaTha and likeminded actors, this didn't stop some Christians from worrying about what the ascendancy of such groups meant for them. For those committed to evangelism, a careful balancing act was required. 'We need to be shrewd as snakes and innocent as doves,' was how Hope's senior pastor put it, with reference to Matthew 10:16, when we met in his office. He went on to stress that, while it behoved Christians to seize new opportunities for evangelism, there was no need to 'advertise' whatever success they might have.

He gave the example of national registration cards, which, in Myanmar, list both a person's 'religion' (batha) and their 'ethnicity' (lumyo). ${ }^{21}$ A convert had little to gain, the pastor felt, from seeking to have their new faith recorded on their registration card. This would be more trouble than it was worth, not least because of the tendency in Myanmar to jumble the categories of religion and ethnicity, meaning that conversion raised the possibility of paradox. It made sense for a person to be 'Chin' and 'Christian', or alternatively, 'Bamar' and 'Buddhist'. But how could a person be 'Bamar' and 'Christian'? Such terms were considered mutually exclusive, especially in the eyes of the local bureaucrats responsible for administering the system of registration cards. There was also the risk that too many converts seeking to amend their cards might draw unhelpful attention to the church. What mattered, again, was what a person believed in their heart, a space inaccessible to the gaze of state officials. Only God could access this space, could know the sincerity of a person's belief, the extent to which they had accepted Jesus into their life - all of which made the new conversion law both irrelevant and ridiculous in the eyes of the pastor. How could the Religious Conversion Scrutinising and Registration Boards it established possibly be expected to make that determination?

Yet the pink post-it note suggested that interiority was not the end of the story. State tools of registration, such as the ID card, were to be avoided; there was little benefit from trying to render one's faith legible via these mechanisms. Still, some form of external registration clearly still mattered for churches such as Hope, and not just in the eyes of God. New believers had their numbers counted. Photographs of their baptisms lined the walls at Hope. Their testimonies were printed in the pages of the church newsletter compiled by the pastor's nephew. Posting on Facebook about a revival event he'd helped organise in 2016, one friend wrote, in English, 'Salvations $200+$ '. In these ways, Christians registered the changes that new believers were thought to have undergone, a registering that also gestured towards the wider context of transition in which they occurred. That they did so whilst evading state attempts to register religious change speaks not only to their desire, in a still uncertain moment, to seek certain forms of recognition while avoiding others. It also gets at the question of what exactly is being registered. For if the ID card or conversion law profess to record a person's religion, what these Christians claim to be recording is a person's belief -

new wunthanu movements in Myanmar', Review of Faith and International Affairs, 13, 4 (2015): 12-24.

${ }^{21}$ On the geneaologies of fraught categories of ethnicity, see Jane M. Ferguson, 'Who's counting? Ethnicity, belonging, and the national census in Burma/Myanmar', Bijdragen tot de taal-, land-en volkenkunde / Journal of the Humanities and Social Sciences of Southeast Asia 171, 1 (2015): 1-28; Aurore Candier, 'Mapping ethnicity in nineteenth-century Burma: When 'categories of people' (lumyo) Became "nations", Journal of Southeast Asian Studies 50, 3 (2019): 346-364. 
two categories they present as not only different but opposite. We attune to the resulting dissonances in the following discussion of the conversion law and its conceptual genealogy.

\section{Bureaucratising belief}

The law stipulated that people seeking to convert needed to apply to one of the new Religious Conversion Scrutinising and Registration Boards for permission to do so. Applicants were to submit a range of details including their age, address, and registration card number. They were also expected to provide the board with their 'reason for converting to the new religion'. The boards would interview applicants to determine whether they were converting voluntarily. They could order the person to pursue further study of their new religion before deciding whether to issue them with a certificate recognising the conversion. Given these baroque prescriptions, it is perhaps unsurprising that human rights groups considered the law discriminatory, that many Christians found it absurd, and that none of the converts I met had any interest in submitting themselves to the onerous procedure it instituted. More surprising, perhaps, is the seemingly innocuous section on the first page of the written version of the law that defines its key terms, particularly the way it defines 'religion' - that is, as 'a system of belief (youn chi) subscribed to by a person. ${ }^{22}$

What to make of the fact that religion is defined here in this way? 'Through complicated patterns of influence,' writes Donald Lopez, 'the representatives of nonChristian religions have come to speak of themselves in terms of belief.' ${ }^{23}$ This is part of a now familiar story about the complex role that colonial governance, missionary activity, and the comparative study of religion have played in establishing and demarcating the category of religion around the world. It is a story about the implications of the West's 'conceptual geology' for the 'ways in which non-Western traditions are now able to grow and change. ${ }^{24}$ Scholars drilling down into this geology in the Burmese context have argued that no clear term for 'religion' existed in the Burmese language prior to the colonial period. The words for 'religion' (batha) and 'Buddhism' (bok'da batha), they suggest, emerge in this context. The word batha had previously been used to refer to language and is still also used this way today. What did exist prior to British arrival was the concept of thathanadaw: a polity structured around the Buddha's dispensation or sasana (thathana in Burmese) and organised around a set of relations between the monarchy, monks, and laity. ${ }^{25}$ Kirichenko shows that Burmese words for 'religion' and 'Buddhism' only appeared after significant contacts with the West. 'These equivalents derived from the work of Christian missionaries,' he suggests, 'who needed them to translate texts and sermons

\footnotetext{
22 'Pyidaungsu Hluttaw Law No. 48/2015, Law Concerning Religious Conversion (Burmese)', http://www.myanmar-law-library.org/law-library/laws-andregulations/laws/myanmar-laws-1988-until-now/union-solidarity-and-developmentparty-laws-2012-2016/myanmar-laws-2015/pyidaungsu-hluttaw-law-no-48-2015-lawconcerning-religious-conversion-burmese.html.

${ }^{23}$ Donald S. Lopez Jr., 'Belief' in Critical Terms for Religious Studies, ed. Mark C. Taylor (Chicago: University of Chicago Press, 1998), p. 21.

${ }^{24}$ Asad, Genealogies of religion, p. 1.

${ }^{25}$ Kirichenko, 'From Thathanadaw to Theravâda Buddhism'.
} 
in the Burmese vernacular. ${ }^{26}$ One theory has it that it was Judson who was responsible for introducing the word 'Buddhism' into Burmese, though doubts remain that any one person could have done so singlehandedly. ${ }^{27}$

In any event, the evidence suggests that at least one force behind the emergence of these categories in Burma was Christian evangelism and the Buddhist response - an encounter in which tracts criticising or defending Buddhism 'helped to domesticate new terms'. ${ }^{28}$ Both Houtman and Kirichenko tell us that the term bok'da batha only entered widespread use in the late nineteenth century. One key difference that Kirichenko highlights between thathanadaw and batha is a newfound emphasis on belief: 'thathanadaw and belonging to it was understood as a number of observances and realisations, not as a set of doctrines or beliefs ... precolonial texts defining model followers of the teaching generally spoke of things to do, not of postulates to believe in or hold as a view. ${ }^{29}$ One person thought to have played a key role in popularising the new term and placing belief at its centre was the influential monk Ledi Sayadaw (1846-1923). In writings that were often a rejoinder to missionary critiques of Buddhism, he came to speak about Buddhism (bok'da batha) as 'quintessentially a system of beliefs' comparable to, and in competition with, other religions. ${ }^{30}$

This is not to suggest that batha came to replace thathana wholesale. On the contrary, the category of thathana remained not only operational under colonialism, but was mobilised in the course of resistance to it. ${ }^{31}$ Today, although MaBaTha's official English title is the Patriotic Association of Myanmar, its full name in Burmese attests to the organisation's claim to protect both batha and thathana. ${ }^{32}$ In his study of the Shwegyin monastic order, Carbine speaks of a process of 'sasana-isation' whereby the figure of thathana came to be increasingly central to Burmese Buddhist life, even as the range of meaning associated with the term remained large. ${ }^{33}$ All the same, what this brief historical detour indicates is how an earlier set of exchanges in a long conversation between Christianity and Buddhism contributed to shaping a category of 'religion' now circulating in Myanmar, one that appears on people's national registration cards and is manifest in the language and logic of the new conversion law - a further reminder that the effects of missionary projects cannot be measured by numbers of converts alone. ${ }^{34}$

Like the Tswana encounter with British missionaries on the South African frontier, Burmese Buddhists were drawn onto a Christian conceptual terrain, even as they

\footnotetext{
${ }^{26}$ Ibid., p. 33.

${ }^{27}$ Houtman, 'How a foreigner invented "Buddhendom" in Burmese', p. 114.

${ }^{28}$ Kirichenko, 'From Thathanadaw to Theravâda Buddhism', p. 34.

${ }^{29}$ Ibid., p. 29.

${ }^{30}$ Braun, The birth of insight, p. 85.

${ }^{31}$ Alicia Turner, Saving Buddhism: The impermanence of religion in colonial Burma (Honolulu: University of Hawai'i Press, 2014)

32 amyo batha thathana saungshaukye apwe

${ }^{33}$ Jason Carbine, Sons of the Buddha: Continuities and ruptures in a Burmese monastic tradition (Berlin: De Gruyter, 2011).

${ }^{34}$ Mahmood, Religious difference in a secular age, p. 47.
} 
challenged Christianity and argued for the superiority of Buddhism. ${ }^{35}$ For the Comaroffs, such moves facilitated the constitution of hegemony through a set of everyday discursive and material processes they term the 'colonisation of consciousness'. Today's evangelists in Myanmar navigate a conceptual terrain partly shaped by the nineteenth-century missionaries to whom they are heirs of a sort. In doing so, however, they often ignore or evade the categories those earlier encounters helped usher into being. When Hope's senior pastor dismisses the conversion law or advises converts against amending their registration cards, he challenges the conflation of religion and belief that scholars have attributed partly to his missionary predecessors. The result is that evangelism becomes an encounter shot through with dissonances: gaps between different definitions of religion that afford certain possibilities to those who pass through them.

Consider what my friend May Lwin told me over lunch at the Dagon Centre 2 shopping mall one month after the NLD's election win. Though her registration card still stated she was 'Buddhist', she was, in fact, one of the most active members of another Pentecostal church in downtown Yangon loosely affiliated with Hope. Run by Chin pastors, with worship conducted in both Burmese and English, the church attracted a mix of attendees that included foreign NGO staff and volunteers. May Lwin stayed at a friend's apartment on weekends so she wouldn't miss services. Her family had once lived nearby but had been forced by rising rents to move from the centre to Hlegu, a small township about $40 \mathrm{kms}$ to the northeast. Now 24 , she told me she had become a believer at 19, when still a physics student at Dagon University. A friend had invited her to a free English class at the church where a volunteer from Argentina encouraged her to read the bible. 'I'm a Buddhist,' she had initially responded, 'so I'm really not interested.' The teacher was persistent, but so was May Lwin. 'Whenever she would speak about Jesus, I would speak about the Buddha.' However, over time, and though regular conversations with the Argentinian, she began, she said, to experience Christ's presence in her life, and also to ask herself a question that would eventually lead her to him: Was she satisfied with travelling through countless cycles of samsara, unsure about the outcome, especially when Jesus offered her certainty about what to expect in her next life? This was a question, she felt, few Buddhists seriously asked themselves. Buddhism, for many, was just 'tradition' (miyopola).

She was planning to look into amending her registration card when it next came up for renewal, notwithstanding the fact that, with 'Bamar' listed as her ethnicity, this was likely to be difficult. Still, her faith was also not something she was keen to announce to an audience of local bureaucrats. 'Why should they have anything to do with my belief?' she asked. 'I don't like it when people say that I have changed my religion,' she told me several months later. 'It's just that I started believing. People here are obsessed with religion.'

The distinction she made here did not imply some syncretic move, some desire to reconcile her new faith in Jesus with a broader field of Buddhist practice. On the

${ }^{35}$ Comaroff and Comaroff, Of Revelation and Revolution, p. 26. For an analysis of how a somewhat analogous process unfolded in nineteenth-century Siam, see Thongchai Winichakul, 'Buddhist Apologetics and a Genealogy of Comparative Religion in Siam', Numen, 62, 1 (2015): 76-99. 
contrary, becoming a believer for May Lwin meant no longer participating in a set of practices she and other believers glossed as religion: visiting the pagoda, offering alms, practicing meditation. The distinction reflected a broader move amongst Pentecostals to disentangle religion from belief. This move was at odds with the definition offered in the conversion law, one that itself bears traces of past exchanges between Christianity and Buddhism. The logic of the law assumes a subject for whom religion is a matter of internal belief and individual choice. That internal belief and individual choice were paramount was a given for believers like May Lwin. But this is precisely what, for them, made religion moot, what took them beyond religion. This was what the state got wrong when it presumed it could assess a person's belief and use it to register their religion. The dissonance between these understandings of religion was useful insofar as it allowed believers to avoid a potentially fraught encounter with the state's attempt to manage religious difference. But the disentangling of religion and belief had not only practical but also theological entailments. It was what allowed evangelists to present Buddhism - the 'tradition' of May Lwin's telling - as the religion par excellence.

\section{Transcending religion}

Evangelists in Myanmar were more likely to speak of 'non-believers' (ma youn chi thu) and 'believers' (youn chi thu) than 'Buddhists' (bok'da batha win) and 'Christians' (cri'yan batha win). This was the case, for example, in the testimonies of 'new believers' (youn chi thu athiq) printed in Hope's church newsletter: 'I used to be a non-believer', was the usual formulation. It is of a piece with the distinction made by May Lwin, one that resonates with Galatians 3:28, a popular bible verse in Yangon churches: 'There is neither Jew nor Gentile, neither slave nor free, nor is there male and female, for you are all one in Jesus Christ.' Much preaching in Myanmar returns to this message. At the revival meeting at People's Park, in the shadow of the Shwedagon Pagoda, one of the preachers, San Toe, explained to the thousands in attendance that Jesus died to counteract the 'demerit' (akutho) they inevitably accumulate through their actions, thoughts, and speech, whatever their 'religion' (batha). All religions are good, he explained, but they have the same message:

Practice on your own. Try on your own. You'll get it only if you do it. But you're not good enough. So you go to hell (nga yeh). ... That's why Jesus came down to earth. This Jesus, he isn't Christian. He's a God that invites people of all races (lumyo), all religions (batha) ... Jesus suffered for all of our demerit on the cross.

Bamar or Chin, Buddhist or Christian, Jew or Gentile: San Toe's framing works to render irrelevant the kind of distinctions that the state uses to organise difference. There is, once again, a pragmatic rationale behind the move. It is useful in a context where it remains dangerous to publically criticise Buddhism. To do so is to risk drawing the ire of those organisations that have tasked themselves with defending batha and thathana, and also poses the hazard of falling foul of a colonial-era law that prohibits insulting a religion - a crime that carries a possible two-year jail term. ${ }^{36} \mathrm{In}$

\footnotetext{
${ }^{36}$ On the recent application of this law, see Iselin Frydenlund, 'The rise of religious offence in transitional Myanmar', in Outrage: The rise of religious offence in
} 
the face of that danger, evangelists stress that they are not interested in 'comparing' (hnain shin) different religions. But there is more to San Toe's move than the desire to escape the attention of nationalists and the state. It also allowed evangelists such as him to present Buddhism as the quintessential religion, even as they avoided calling it by name. In the discourse of evangelism, 'religion' comes to stand for 'Buddhism'. We will see how this played out in the way that evangelists spoke with Buddhist interlocutors. But first I want to consider the tracts often used by evangelists, and in which the positioning of Buddhism as religion can be clearly seen.

'The Drowning Man' (ye niq thu) was a favourite in churches such as Hope. Few gospel trips were complete without evangelists distributing dozens of copies. It describes what happens to a man who dives into a lake, ignoring a nearby sign that clearly says 'no swimming'. After he starts to drown, a bystander attempts to save him by standing on the shore and demonstrating how to swim: 'You have to move your arms like this'. Another passer-by then admonishes the man: 'Didn't you read the sign?!' Finally, a third person dives in and saves him, saying, 'Don't be scared, friend. I'm coming.' It is, according to those who distribute the tract, a culturally sensitive rendering of the gospel that avoids mentioning either Buddhism or Christianity. The hope is that it prompts Buddhists to ask themselves the question that ultimately led May Lwin to Jesus. We know that our inability to follow rules and instructions leaves us drowning in samsara. Jesus is offering to dive in and rescue us. Why not accept him?

I met the author of 'The Drowning Man' in June 2016 at his office close to Yangon's airport. Born into a Buddhist family, he had converted to Christianity while attending university in the UK. He told me that when God gave him the vision to write the tract, it was with Buddhists specifically in mind. The challenge was how to do so without mentioning Buddhism. Drawing on his background, he wrote the story about the drowning man as a way to hone in on what he saw as the centrality of 'law' or taya in the practice of Burmese Buddhism. The pamphlet includes the line, 'If you break the law, the law cannot save you.' The point was to contrast this with the 'grace' (che zu daw) that comes through Jesus. Like other terms discussed in this paper, taya is not simple to define. It can refer to law, truth, and justice, and also the dhamma that the Buddha taught. ${ }^{37}$ It is thus central to what Matthew Walton refers to as an overarching 'moral universe' organised around natural laws of cause-and-effect. ${ }^{38}$ Evangelism turns on the distinction between the law of karma that structures this universe and the grace that transcends it. ${ }^{39}$

contemporary South Asia, ed. Paul Rollier, Kathinka Frøystad and Arild Engelsen Ruud (London: UCL Press, 2019), pp. 77-102.

${ }^{37}$ Matthew Walton, Buddhism, politics, and political thought in Myanmar

(Cambridge: Cambridge University Press, 2017), p. 45-6.

${ }^{38}$ Ibid.

${ }^{39}$ For further discussion of how this played out through moments of translation, see Michael Edwards, 'Public misunderstanding: Translating salvation in Myanmar's transition', Comparative Studies of South Asia, Africa and the Middle East, Forthcoming. On a comparable move and its implications in Sri Lanka, see Neena Mahadev, 'Karma and grace: Rivalrous reckonings of fortune and misfortune', $H A U$ : Journal of Ethnographic Theory, 9, 2 (2019): 421-438. 
In the tract, the former is represented in the figures of the first two people who approach the drowning man, offering instructions ('You have to move your arms like this') or reprimands ('Didn't you read the sign?!'), but leaving him to bear the consequences of his actions. The latter is represented by the third figure, intervening directly to save the suffering man. This distinction animates the way evangelists attempted to engage their Buddhist interlocutors. Hope regularly sent teams of evangelists to areas throughout Yangon, often to townships like Shwepyitha and Hlaingthaya on the city's fringe. Other churches had evangelism programs, but few matched Hope's ambition, a manifestation of the vision God had given the senior pastor in the late 1980s. Teams were made up of staff, volunteers, and students enrolled in the church's bible college, many of whom have travelled to Yangon from Chin State. In September 2016, I accompanied a small group led by Suan, one the church's evangelists, to Thaketa, an area east of the downtown. In her late twenties, Suan had served at the church since she was a teenager. She had previously been assigned to Thanlyin, a township over the other side of the Bago River. Equipped with stacks of pamphlets, the group walked through the neighbourhood asking residents if they had time to talk.

The first person they spoke to that day was a 70-year-old woman. We sat on the floor of her house as she continued folding her laundry. A football match and recent rock concert featuring the band Iron Cross played on the TV in the background. Suan started by jotting down the woman's name in a small notebook. She then said she would like to speak to the woman about what happens after we die. 'As far as I understand it,' Suan said, 'in Burma, there's something like religion (batha taya), right?' She continued,

People live under religion (batha taya). What it means is, ah, if you do good, you'll get good (kaun da louq yin kaun da ya meh).... As to what religion is, it instructs us, right? Parents, for example, teach children not to curse, not to make noise, to treat adults well. ... Now, people keep uposatha (Buddhist observance days), right? People go to pagodas, right? ... Only by this, then, when one dies, they might arrive at somewhere good or arrive at somewhere not good, right? [But] one thing for sure is, it won't get us to heaven.

The formulation employed here - 'If you do good, you'll get good' - is used in sermons by Buddhist monks in Myanmar. It refers to the accumulation of merit necessary to guarantee a good rebirth and eventual release from samsara. Evangelists like Suan take this causal logic to be the quintessence of religion. In preaching, the "old covenant" and the apparent premium it places on adherence to the law becomes a kind of shorthand for karma. To be 'no longer under the law' (Romans 6:14) might thus be to have one's salvation no longer subject to its logic and the moral universe it organises. Suan's point was that "religion" can teach us to live well but cannot rescue us from drowning. 'We are trying to teach them that religion won't save them,' was how another evangelist put it. I noted above that this resonates with a familiar Christian move, one whereby Christianity attempts to 'liberate itself, to excoriate 
itself from its own conditions ... judg[ing] itself no longer Christian, no longer religious. $^{, 40}$

For evangelists like Suan, however, religion comes to index Buddhism specifically. Or rather, it indexes a partial and strategically useful image of Buddhism. This image of Buddhism - a system of cause and effect contingent on individual effort without recourse to the divine - elides the heterogeneity that constitutes actual Buddhist life in Myanmar and neighbouring countries. ${ }^{41}$ But it affords evangelists a stark counter against what they claim Jesus can offer. Recall San Toe's characterisation: 'Practice on your own ... You'll get it only if you do it.' In other words, one thing that makes Buddhism a religion in the eyes of these Pentecostals is, in fact, its apparent secularity - insofar as it is reduced to the rationalistic and disenchanted functioning of a causal mechanism. The religious and the secular here get folded into the same field of action, against which Christ promises something other and transcendent.

One irony is that it is this same image of Buddhism, with its emphasis on actions and consequences, shorn of superstition or intercession, which has led many to make claims about its compatibility with a secular view of the world. ${ }^{42}$ This is part of the subtle story Ruth Streicher tells in her contribution to this collection with respect to the writing of the Kitchanukit in nineteenth-century Siam. It is what has led some to claim - in an echo of what Pentecostals here suggest about their own faith but for almost the opposite reason - that Buddhism is not a religion. This image emerges in part out of the same long conversation, between Buddhists and Christians, often under conditions of colonialism, which helped produce the definition of religion now found in Myanmar's conversion law. ${ }^{43}$

For evangelists, to live within the universe that this image presents - to sink or swim according to how well one can follow its laws - might be to live inside a version of what Charles Taylor calls the "immanent frame": the disenchanted space of selfreliant "buffered selves", closed off from the transcendent, which he presents as a hallmark of a secular age. ${ }^{44}$ There is not quite the accompanying "exclusive humanism" that appears in Taylor's analysis. Suan and other evangelists work from

\footnotetext{
${ }^{40}$ Anidjar, 'Secularism', p. 60

${ }^{41}$ See, for example, Bénédicte Brac de la Perrière, 'Spirit possession: An autonomous field of practice in the Burmese Buddhist culture', Journal of Burma Studies, 20, 1 (2016): 1-29; Guillaume Rozenberg, The immortals: Faces of the incredible in Buddhist Burma (Honolulu: University of Hawai'i Press, 2015); Jane M. Ferguson, 'Terminally haunted: Aviation ghosts, hybrid Buddhist practices, and disaster aversion strategies amongst airport workers in Myanmar and Thailand', The Asia Pacific Journal of Anthropology, 15, 1 (2014) 47-64; Justin McDaniel, The lovelorn ghost and the magical monk: Practicing Buddhism in modern Thailand (New York: Columbia University Press, 2011).

${ }^{42}$ Donald S. Lopez, Jr. Buddhism and science: A guide for the perplexed (Chicago: University of Chicago Press, 2008).

${ }^{43}$ For further discussions of this conversation's trails see, for example Anne M. Blackburn, Locations of Buddhism: Colonialism and modernity in Sri Lanka. (Chicago: University of Chicago Press, 2010); Philip C. Almond, 1988 The British Discovery of Buddhism (Cambridge: Cambridge University Press, 1988).

${ }^{44}$ Charles M. Taylor, A secular age (Cambridge: Harvard University Press, 2007).
} 
the assumption that their Buddhist interlocutors are, like them, deeply interested in otherworldly salvation. But in how evangelists present the gospel as a path toward this end, Buddhist selves get cast as buffered selves. The twist is that it is the buffered - or secular - state of these selves that makes them so religious.

\section{Conclusion: Definitional dissonance}

People are obsessed with religion, was how May Lwin put it. Scholars of Myanmar especially, we might add. Religion has been a central concern of researchers, especially anthropologists, since at least the 1960s. ${ }^{45}$ While non-Buddhist traditions have in recent years drawn increasing attention, ${ }^{46}$ scholars working on religion have more often adopted what Bénédicte Brac de la Perrière calls a 'Buddhism-centric view'. ${ }^{47}$ The overwhelming focus on Theravada Buddhism serves, she writes, to not only re-enforce the centrality of Buddhism to Burmese narratives of national belonging, but also, through its focus on a set of apparently 'orthodox' practices, to elide the heterogeneity of Burmese Buddhism most visible in the nat spirit cult. ${ }^{48} \mathrm{~A}$ second irony: The result of this 'Buddhism-centric view' is an echo of the move made by the evangelists discussed here: religion in Myanmar comes to mean not just Buddhism, but a particular version of it.

In this paper I have tracked some of the work performed by the category of religion over the course of a long conversation between Buddhism and Christianity. In doing so I have responded to recent calls to consider how it and other key terms get defined and deployed in and about Myanmar, helping to unsettle some of the conceptual grammar on which analysis of recent events is often grounded. A caveat is in order: To question this grammar is not to reject the claim this analysis is frequently used to make - that is, that greater state neutrality, with respect to Buddhism, Islam, and Christianity, would improve the situation for Myanmar's minorities. As I was revising this paper in early 2020, David Lah, one of the preachers at the People's Park event, was arrested and put on trial. The charge was that he had allegedly held worship services in the Yangon township of Insein in defiance of social distancing restrictions in place to fight the coronavirus pandemic. ${ }^{49}$ While many Christians were ambivalent

\footnotetext{
${ }^{45}$ Juliane Schober, 'Communities of interpretation in the study of religion in Burma', Journal of Southeast Asian Studies, 39, 2: 255-267.

${ }^{46}$ See, for example, Nyi Nyi Kyaw, 'Alienation, discrimination, and securitization: Legal personhood and cultural personhood of Muslims in Myanmar', Review of Faith and International Affairs, 13, 4 (2015): 50-59; Elizabeth Rhoads, 'Property in transition: Uncertainty, agency and belonging in Yangon, Myanmar' $(\mathrm{PhD}$ Dissertation, King's College London, 2019); Melissa Crouch, ed., Islam and the state in Myanmar: Muslim-Buddhist relations and the politics of belonging (Oxford: Oxford University Press, 2016).

${ }^{47}$ Bénédicte Brac de la Perrière, 'An Overview of the Field of Religion in Burmese Studies', Asian Ethnology, 68, 2: 196.

${ }^{48}$ Ibid.

49 'Myanmar Pastors Face Prosecution for Defying Ban on Religious Gatherings Amid COVID-19', The Irrawaddy, 14 April 2020, https://www.irrawaddy.com/specials/myanmar-covid-19/myanmar-pastors-face-
} 
about the case, some saw it as the playing out of a familiar pattern of discrimination, pointing to Buddhist events that had apparently gone ahead under lockdown without arrests being made. It is against this backdrop that the definitional dissonance discussed here becomes productive, not just in providing the conceptual scaffolding for evangelism, but also in helping believers evade the gaze of the state and its efforts to regulate religious difference.

Responding to the activities of Christian missionaries during the colonial period, the monk Ledi Sayadaw and others came to speak of 'Buddhists' and 'Christians': followers of religions defined as comparable systems of belief. We have seen that the Pentecostals discussed here were less keen on these terms, preferring to speak of 'non-believers' and 'believers', the latter denoting a person whose salvation is no longer dependent on a karmic logic that is, in their eyes, both deeply religious and deeply secular. The path from Adoniram Judson to Ledi Sayadaw to today's conversion law contains a series of dissonances, slippages where the categories of religion and belief come together and fall apart again: where, for state law, religion comes to mean belief; where, for the evangelists, religion comes to mean Buddhism; and also where, in a clear reminder of the limitations and ambiguities of such categories, those sharing the gospel appear to position themselves in opposition to both religiosity and secularity. Such moments of dissonance become most audible at moments when the state's regulation of religion appears to stumble. When, for example, the colonial state in Burma in the late nineteenth century tried to engage Buddhist monastic schools in its education program - and in doing so attempted to circumscribe the boundaries of 'religious' and 'secular' subjects - many monks refused to participate. ${ }^{50}$ 'The monks were not interested in participating in the creation of Buddhism as a religion because this did not serve their ends,' which, in their case, was the protection and promotion of the thathana. ${ }^{51}$

Something similar could be said of the evangelists here and their evasion of state attempts to regulate religion in the form of registration cards and a conversion law. If salvation depends only on belief, it has nothing to do with these state projects, even as these same projects have come to define religion in terms of belief. As with the encounter between the Tswana and British missionaries, this is a long conversation that brings into dialogue 'divergent cultural perspectives, dissimilar intentions, dissonant notions of value'. ${ }^{52}$ But we have seen in this paper how the persistence of definitional dissonance allows interlocutors to operate at cross-purposes. This is not to deny that relations between religions in Myanmar have and continue to be deeply unequal, often violently so, as recent years have confirmed with shocking clarity. It is, rather, to show how they have not everywhere and always been unequal in the same

prosecution-defying-ban-religious-gatherings-amid-covid-19.html (accessed 14 April 2020).

${ }^{50}$ Alicia Turner, 'Religion-making and its failures: Turning monasteries into schools and Buddhism into a religion in colonial Burma' in Secularism and Religion-Making, ed. Markus Dressler and Arvind-Pal Mandair, (Oxford: Oxford University Press, 2011).

${ }^{51}$ Ibid., p. 238.

${ }^{52}$ Jean Comaroff and John L. Comaroff, Of revelation and revolution: Christianity, colonialism, and consciousness in South Africa, Volume 2 (Chicago: University of Chicago Press, 1997), p. 6. 
sort of way. What the Comaroffs term the 'colonisation of consciousness' is difficult to parse in a conversation that has and continues to be punctuated by so many inversions pivoting around religion.

'More successful anthropological approaches to religion,' suggests Michael Lambek, 'begin with acts of making and doing rather than in the articulation of personal experience or beliefs ... From this perspective, belief and experience are secondary phenomena when it comes to discerning, distinguishing (or, for that matter, explaining) religion ..., 53 In making this claim, Lambek picks up on anthropology's recent reflection on its own Christian inheritance, particularly the way the discipline had once assumed a definition of religion inflected by a Protestant emphasis on individual belief - an assumption now subject of extensive critique. A third irony: The Pentecostals discussed here would be quick to endorse Lambek's claim. Indeed, whenever I introduced myself to one of them by saying I was interested in studying 'religion', they told me I was going about it in a rather odd fashion. Shouldn't I be spending my time with Buddhists, which is to say with people actually practising religion? If I insisted instead on hanging out with them, I might struggle to learn much about the topic because it wasn't something in which they had much interest.

Not that they had much interest in secularism either, if by that we mean, not only the state management of religion that Mahmood and others have shown its forms of governance entail, but also the settlement it's generally taken to denote: one that mandates the retreat of faith from a public to a private sphere. Quite the contrary, especially if the enthusiasm of those celebrating new freedoms to preach publically in People's Park and elsewhere is any indication. What becomes clear, rather, is an ongoing reworking of the conceptual ground on which a secular settlement might depend - a reworking that has played out, in part, through the course of the BuddhistChristian encounter and continues into the present. The evangelists here remind us that if their exchanges with Buddhists are part of a long conversation, it's one with so many slippages that the interlocutors often appear to be speaking past each other. But they also invite us to attune to these dissonances, listening not just for reverberations of colonial and postcolonial histories, but also for the gaps from which might emerge alternate ways of approaching religion - however defined - in and beyond Myanmar.

\footnotetext{
${ }^{53}$ Michael Lambek 'Facing religion, from anthropology', Anthropology of this Century, 4 (2012), http://aotcpress.com/articles/facing-religion-anthropology/ (accessed 27 May 2018).
} 